\title{
Patterns of plant species composition in mesic woodlands are related to a naturally occurring depth-to-groundwater gradient
}

\author{
M.C. Hingee ${ }^{1}$, D. Eamus ${ }^{1}$, D.W. Krix ${ }^{1}$, S. Zolfaghar ${ }^{1}$ and B.R. Murray ${ }^{1,2}$ \\ ${ }^{1}$ School of Life Sciences, University of Technology Sydney, PO Box 123, NSW 2007, Australia \\ ${ }^{2}$ Corresponding author: Email: Brad.Murray@uts.edu.au, Phone: + 6129514 4075, Fax: + 61295144079
}

Keywords: Abundance, Environmental attributes, Groundwater-dependent ecosystem, Groundwater extraction, Species richness.

\begin{abstract}
Groundwater-dependent ecosystems (GDEs) are threatened by over-extraction of groundwater for human needs across the world. A fundamental understanding of relationships between naturally occurring gradients in depth-to-groundwater (DGW) across landscapes and the ecological properties of vegetation assemblages is essential for effective management of the impacts of groundwater extraction. Little is known, however, about relationships between DGW and the ecology of mesic woodlands in GDEs. Here, we investigated relationships between a naturally occurring DGW gradient and plant species composition, richness and abundance in mesic Eucalyptus woodlands of eastern Australia. Across 16 sites varying in DGW from 2.4 $\mathrm{m}$ to $43.7 \mathrm{~m}$, we found that plant species composition varied significantly in relation to DGW, independently of a range of 14 physical and chemical attributes of the environment. Nine understorey species, representing only $7 \%$ of the pool of 131 plant species, were identified as contributing to up to $50 \%$ of variation in species composition among the study sites. We suggest this dominant pattern driver in the understorey is explained by differential abilities among understorey species in their ability either to tolerate extended dry conditions at deeper DGW sites during periods of low rainfall, or to withstand periodically waterlogged conditions at shallow sites. Plant species richness and total plant abundance (a measure of plant productivity) were not significantly and independently related to DGW or any of the other 14 environmental attributes. Our finding for a direct relationship between DGW and plant species composition provides important reference information on the ecological condition of these mesic woodlands in the absence of groundwater extraction. Such information is vital for setting ecological thresholds that ensure sustainable extraction of groundwater.
\end{abstract}

Nomenclature: PlantNET (The NSW Plant Information Network System). Royal Botanic Gardens and Domain Trust, Sydney. http://plantnet.rbgsyd.nsw.gov.au

Abbreviations: DGW - Depth-to-GroundWater, GDE - Groundwater-Dependent Ecosystem, HSSGW - Highlands Sandstone Scribbly Gum Woodlands, HSTOF - Highlands Shale Tall Open Forests, NESW - Nepean Enriched Sandstone Woodlands, SCA - Sydney Catchment Authority.

\section{Introduction}

Groundwater-dependent ecosystems (GDEs), which must have access to groundwater to maintain their ecological structure and function (Hatton and Evans 1998), are threatened globally by groundwater extraction for human consumption and industry (Murray et al. 2003, Nevill et al. 2010, Brown et al. 2011, Kløve et al. 2014, Eamus et al. 2015). Declines in depth-to-groundwater (DGW) due to extraction can have serious impacts on the ecological properties of vegetation in GDEs, including plant species composition, richness and abundance (Groom et al. 2000, Chen et al. 2006, Sommer and Froend 2014). Worryingly, groundwater is being accessed for human needs at an increasing rate (Konikow and Kendy 2005, Wada et al. 2010). In Australia in particular, utilisation of groundwater for human consumption has increased exponentially in the past 150 years and groundwater is being overextracted in many catchments (Eamus et al. 2006a, Polglase and Benyon 2009). Given the threats posed to GDEs, it is crucial that all efforts are made to provide a comprehensive understanding of relationships between vegetation properties and DGW, especially in areas that have not yet experienced groundwater extraction. A fundamental, baseline understanding of the role that naturally occurring gradients in DGW play in shaping ecological patterns in plant communities will contribute to the effective management and mitigation of the impacts of groundwater decline (Murray et al. 2006, Jakeman et al. 2016, Mendes et al. 2016).

In riparian forests and in arid and semiarid regions of the world, DGW from the soil surface has extensively been shown to have a strong influence on plant ecophysiology, ecosystem function and vegetation properties (Stromberg et al. 1996, Zhu et al. 2013). In contrast, much less is known about relationships between DGW and ecological properties of vegetation in mesic environments. Yet, in mesic regions, plants are known to access groundwater (Eamus et al. 2006b) and recent work has begun to show that DGW influences plant physiology and productivity (Zolfaghar et al. 2014, 2015). For instance, along naturally occurring DGW gradients in mesic woodlands, areas with shallow DGW have 
larger aboveground biomass and net primary productivity than areas where groundwater is much further away from the surface (Zolfaghar et al. 2014). These patterns provide a strong indication that the ecological properties of vegetation in mesic environments will also be related to naturally occurring gradients in DGW (Eamus et al. 2006a).

In this study, we investigated relationships between the ecological properties of mesic woodland vegetation and a naturally occurring DGW gradient of an eastern Australian GDE. Specifically, we addressed the question, do plant species composition, species richness and total plant abundance change in a systematic way in relation to variation in DGW across the landscape? In the study region, DGW ranges from shallow, where groundwater is well within the plantrooting zone (i.e., $<10 \mathrm{~m}$ ) and where rainfall can saturate soils, to deep where DGW exceeds $20 \mathrm{~m}$ (Canadell et al. 1996, Cook et al. 1998, Benyon et al. 2006, O'Grady et al. 2010). Importantly, there has been no extraction of groundwater for human consumption or industry in the study region (Zolfaghar et al. 2014). A key feature of our approach is that we adopted analytical techniques which allowed us to identify any role played by DGW in shaping the ecological properties of vegetation, independently of a range of other physical and chemical attributes of the environment that could influence vegetation properties.

\section{Methods}

\section{Study region and sites}

The study region (Fig. 1) was located $100 \mathrm{~km}$ south-west of Sydney in Kangaloon ( $34^{\circ} 50^{\prime}$ '20’ S, $150^{\circ}$ 56” 74' E) on the Woronora Plateau in eastern Australia. This region has an average annual rainfall of approximately $1067 \mathrm{~mm}$ (20002012, Bureau of Meteorology station no. 68243). The largest monthly rainfall occurs in the Austral summer (February, average of $186 \mathrm{~mm}$ ) and the lowest in Austral winter (August, average of $51 \mathrm{~mm}$ ). Average minimum temperature occurs in July $\left(2.7^{\circ} \mathrm{C}\right)$ and average highest temperature in January $\left(24.3^{\circ} \mathrm{C}\right)$. The largest maximum daily temperature is $40^{\circ} \mathrm{C}$ and lowest daily temperature is $5.1^{\circ} \mathrm{C}$. Total rainfall was $1561 \mathrm{~mm}$ in 2011 and $1188 \mathrm{~mm}$ in 2012, which were 46\% and $11 \%$ larger than the long term average $\left(1067 \mathrm{~mm} \mathrm{yr}^{-1}\right.$; 2000-2010). During 2011 and 2012 rainfall was received on more than 415 days. Mean summer and winter temperatures were $16^{\circ} \mathrm{C}$ and $7^{\circ} \mathrm{C}$ respectively. Thus the climate of these sites is best described as temperate mesic with warm summers and cool winters. Vapour pressure deficit (VPD) was very low (mean summer and winter VPD were 0.45 and 0.25 $\mathrm{kPa}$, respectively) and generally remained below $1 \mathrm{kPa}$ during 2011 and 2012, considerably lower than normal. Thus the long term annual average (1990-2016) total solar radiation

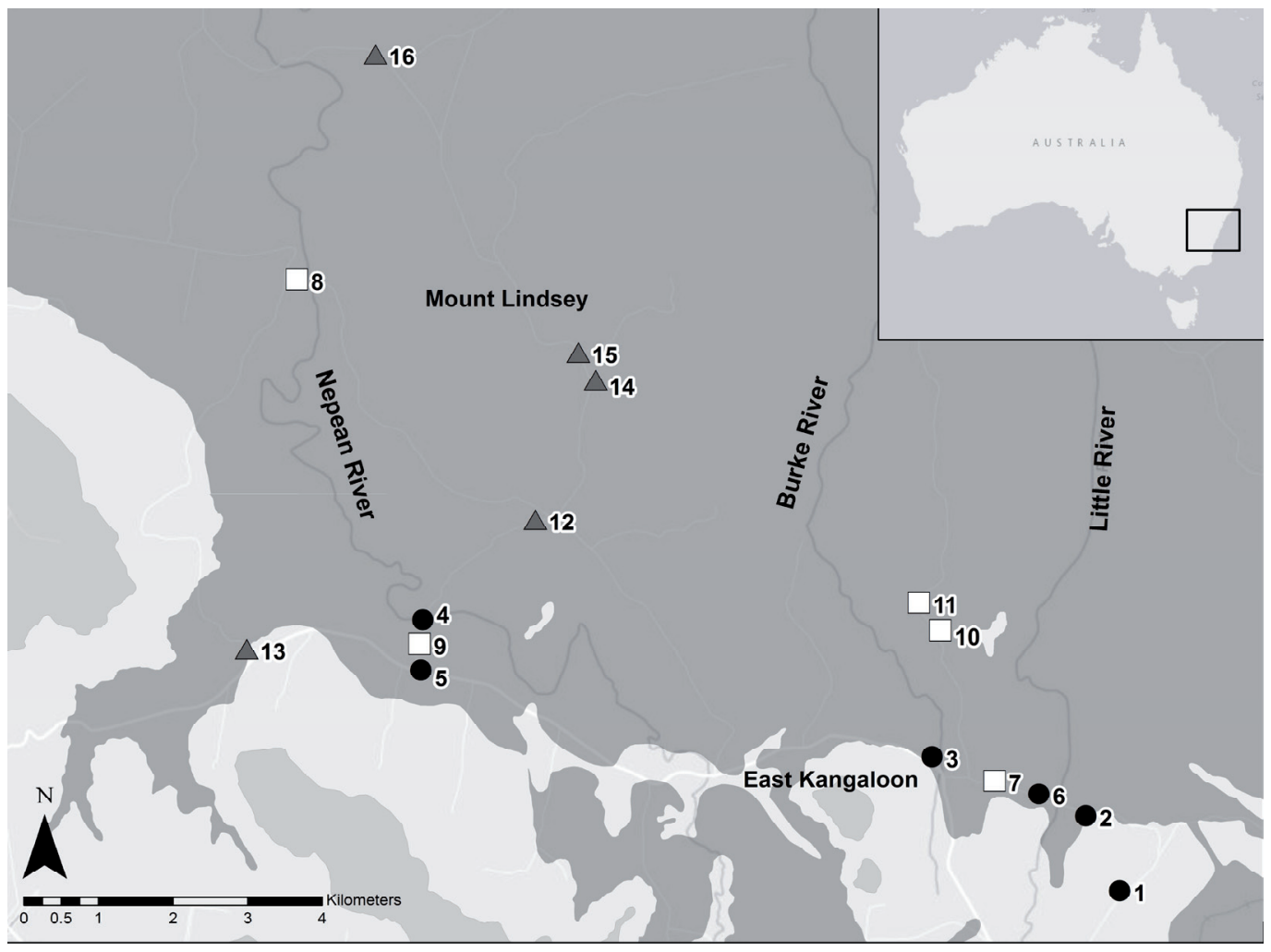

Figure 1. The Kangaloon study region, $100 \mathrm{~km}$ south-west of Sydney ( $34^{\circ} 50^{\prime \prime} 20^{\prime} \mathrm{S}, 150^{\circ} 56^{\prime \prime} 74^{\prime} \mathrm{E}$ ) in eastern Australia. Depthto-groundwater 2-10 $\mathrm{m}$ at sites 1 to 6 (closed circles), 12-22 $\mathrm{m}$ at sites 7 to 11 (open squares), and 27-44 $\mathrm{m}$ at sites 12-16 (closed triangles). . Dark grey areas $=$ Hawkesbury Sandstone, mid grey areas $=$ Robertson Basalt and light grey areas $=$ Wianamatta Shale. Data provided by the Sydney Catchment Authority. 
was $15.7 \mathrm{MJ} \mathrm{m}^{-2}$ and the lowest annual mean occurred in $2011\left(14.1 \mathrm{MJ} \mathrm{m}^{-2}\right)$ which reflected the cloudy and wet conditions of 2011. In 2010, the annual average total solar radiation was $15.2 \mathrm{MJ} \mathrm{m}^{-2}$, close to the long term mean. It is apparent that 2011 and 2012 were wetter, cooler and more humid than the long-term average values.

Remnant Wianamatta Shale overlies Hawkesbury Sandstone in the region and Tertiary Basalt occurs at higher elevations (Kodela 1990). The surficial geology of the area is dominated by a thick sequence of relatively flat-lying Middle Triassic Hawkesbury Sandstone which constitutes the main 'hard rock' groundwater source for the Sydney Catchment Authority's prospective GW resource to drought-proof Sydney. The Hawkesbury Sandstone is made up of sheetlike to massive interbedded formations of mostly medium to coarse quartz sandstone with occasional to locally numerous, thin interbedded mudrock units. The Hawkesbury Sandstone in the Kangaloon area is partly overlain by the Mittagong Formation and the younger Wianamatta Group (Ashfield Shale). Beneath the Hawkesbury Sandstone are sedimentary rocks of the Narrabeen Group. Recharge is predominantly during large rainfall events which tend to be concentrated in the first 6 months of the year. Estimated rates of recharge are in the region of $3 \%$ of annual rainfall. The significant aquifers within the area are porous sandstone beds above a more impervious layer. The main aquifers of the area are within Robertson Basalt and Hawkesbury Sandstone with groundwater in the basalt mainly limited to higher regions of the catchment. Groundwater in the aquifers is recharged by rainfall along ridgelines and discharges in mid-slope areas providing base-flow to several small streams and springs.

Within the study region, the Sydney Catchment Authority (SCA) has in place a series of groundwater monitoring bores. We established a study site within $25 \mathrm{~m}$ of every groundwater bore that was located at least $100 \mathrm{~m}$ from human disturbances such as roads, walking paths and fire trails (these 16 sites are detailed in Appendix 1). Across all sites, variation in annual rainfall is minimal as the sites are all within $11 \mathrm{~km}$ of each other. Each site was 0.1 ha $(20 \mathrm{~m} \times 50 \mathrm{~m})$ in area and DGW data for all study sites, which varied from $2.4 \mathrm{~m}$ to $43.7 \mathrm{~m}$, were provided by the SCA (Fig. 2, Appendix 1).

\section{Vegetation of the region and plant surveys}

Three main vegetation types are found in the region (NPWS 2003), including Nepean Enriched Sandstone Woodlands (NESW), Highlands Sandstone Scribbly Gum Woodlands (HSSGW) and Highlands Shale Tall Open Forests (HSTOF). The vegetation of HSTOF is part of the Southern Highlands Shale Woodlands, an endangered ecological community under the NSW Threatened Species Conservation Act 1995 and a critically endangered ecological community under the Federal Environmental Protection Biodiversity Conservation Act 1999. The vegetation of HSTOF is characterized by an overstorey of Eucalyptus species ranging from 25 to $30 \mathrm{~m}$ in height, a predominance of midstorey shrubs from the Proteaceae and Fabaceae, and an understorey of scattered rushes, ferns and grasses from the
Poaceae, Lomandraceae and Denstaedtiaceae. The vegetation of NESW is characterized by an overstorey of Eucalyptus species ranging from 25 to $35 \mathrm{~m}$ in height, a midstorey of shrubs mainly from the Proteaceae, Myrtaceae and Fabaceae, and an understorey of grasses, rushes and herbs from the Cyperaceae, Lomandraceae, Phormiaceae and Poaceae. The canopy of HSSGW is dominated by Eucalyptus sclerophylla approximately $15 \mathrm{~m}$ in height, and there is a midstorey dominated by shrubs in the Proteaceae and an understorey of grasses, herbs and rushes from the Poaceae, Restionaceae, Cyperaceae and Goodeniaceae.

We performed exhaustive plant surveys across the whole area of each site $(20 \mathrm{~m} \times 50 \mathrm{~m})$, recording the presence of all vascular plant species and the abundance of each species (Appendix 2). These woodlands typically do not have a high representation of annuals across the year and are dominated by perennial species (NPWS 2003). Our initial vegetation surveys were conducted between March and July 2012. We then revisited all sites during the following spring and summer and further surveys did not detect any new species. Abundance was measured using counts of individuals 1, 2, 3, $4,5,6,7,8,9,10,15,20,30,40,50,100,500,1000, \geq 1500$ (Sivertsen 2009). For the purposes of the present study, individual trees were defined as single or multi-stemmed woody plants greater (or potentially greater) than $5 \mathrm{~m}$ in height; individual shrubs were defined as single or multi-stemmed woody plants between 0.5 and $5 \mathrm{~m}$ tall with multiple stems thinner and younger than typical mature tree trunks; and individual groundcover plants were defined as single graminoid, forb, woody, non-woody climbers and ferns up to $0.5 \mathrm{~m}$ tall (Pérez-Harguindeguy et al. 2013).

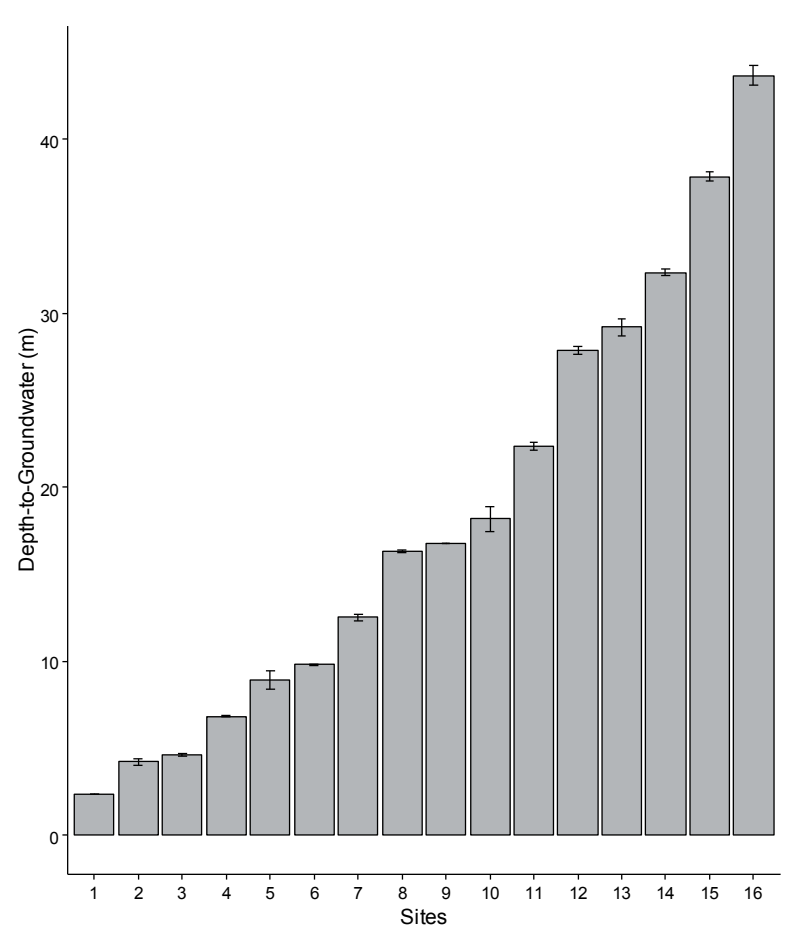

Figure 2. Annual mean depth-to-groundwater ( $\pm \mathrm{SE}$ ) at each of the study sites in the Kangaloon study region from 2006 to 2012. 


\section{Site environmental attributes}

We measured a total of 14 environmental attributes at each site (Appendix 3). Soil samples were collected at the same time that the vegetation surveys were performed and subsequently analysed in the laboratory in July and August 2012. Site slope was determined with a hand-held clinometer and reported as degrees from horizontal. Altitude was determined with a hand held GPS (Garmin eTrex H, reported as $\mathrm{m}$ above sea level). A shade index (measured between 11:00 a.m. and 1:00 p.m.) was determined as the ratio of the amount of photosynthetically active radiation (PAR, measured in $\mu \mathrm{mol} \mathrm{m}-2 \mathrm{~s}^{-1}$ ) above the canopy (or in a nearby open area) to the amount of PAR measured at $1.5 \mathrm{~m}$ beneath the canopy. Three replicate measurements were taken randomly within each site with a Li-Cor PAR sensor (model 250A). A total of 11 soil attributes were measured, with eight to ten soil samples collected along multiple diagonal transects, bulked and mixed thoroughly to obtain a representative sample. Samples were obtained via a stainless steel soil corer $(3 \mathrm{~cm}$ diameter) to a depth of 10 to $15 \mathrm{~cm}$, after brushing aside any surface leaf litter. In plots where the soil was too rocky or shallow, samples were obtained with a stainless steel trowel. Prior to analyses, bulked soil samples were air dried at ambient laboratory conditions for approximately two weeks. Soil peds were crushed by hand using a mortar and pestle and passed through a mesh $(2 \mathrm{~mm})$ screen. Soil $\mathrm{pH}$ and electrical conductivity (EC) were determined using a WTW multi-probe (model 3400) on soil extracts with a 1:2 ratio of soil to water after shaking for one hour (Jones 2001). Organic matter content was estimated by loss on ignition (Jones 2001) and field capacity (FC) determined via gravimetric methods (Hillel 1971). Estimates of particle size were determined through a particle size analyser (MALVERN Mastersizer 2000) after pre-treatment of $250 \mathrm{mg}$ soil samples with $2 \mathrm{ml}$ of $0.5 \%$ CALGON (sodium polyphosphate) solution for $48 \mathrm{~h}$ and in line ultra-sonication for five minutes. Only two fractions were considered, fine fraction (clay) whose particles were $<$ $0.39 \mu \mathrm{m}$, and course fraction (sand) whose particles ranged between $>62.5 \mu \mathrm{m}$ and $<2000 \mu \mathrm{m}$. Total nitrogen $(\mathrm{N})$ was analysed on a carbon/nitrogen analyser (LECO Tru-Spec CN628). Phosphorous $(\mathrm{P})$, potassium $(\mathrm{K})$, magnesium $(\mathrm{Mg})$ and Calcium $(\mathrm{Ca})$ were analysed by inductively coupled plasma mass spectrometry (ICP-MS) after digestion with nitric acid (Krishnamurty et al. 1976).

\section{Statistical analyses}

We used canonical correspondence analysis (CCA) to examine variation in plant species composition among the study sites in relation to DGW and the environmental attributes (Ter Braak 1987). A forward-fitting model selection procedure was implemented to determine whether DGW and any of the environmental attributes could significantly and independently explain variation in species composition. The speciesby-site dataset was populated with square-root transformed abundance data to reduce any bias due to contributions of highly abundant species and to avoid under-representation of lower abundance species in the analyses (Thorne et al. 1999, Legendre and Gallagher 2001). Redundancy was verified by checking variance inflation factors (VIF) and relationships were tested using Monte Carlo permutation tests $(\mathrm{N}=1000)$.

A similarity percentage analysis (SIMPER) procedure (Clarke 1993) was used to determine those plant species that were major contributors to any observed changes in species composition as a function of DGW. For this analysis, sites where DGW was $<10 \mathrm{~m}$ were classed as shallow, sites where DGW was between 12 and $22 \mathrm{~m}$ were classed as intermediate, and sites where DGW was between 27 and $44 \mathrm{~m}$ were classed as deep (Canadell et al. 1996, Cook et al. 1998, Benyon et al. 2006, O'Grady et al. 2010).

Relationships between DGW and species richness, and DGW and total plant abundance, were examined using generalized linear regression modelling (McCullagh and Nelder 1989). Total plant abundance was measured as the summed abundance across all species within a site and represents an estimate of plant productivity. The response variables richness and total plant abundance were in the form of counts, requiring the use of a Poisson error structure with a log link function in models (Crawley 2007). We included an observation-level random effect term in models to avoid over-dispersion (Bolker et al. 2009). We built minimum adequate models (MAMs) to identify whether any of the explanatory variables (DGW and the environmental attributes) were significantly and independently related to either of the response variables (Quinn and Keough 2002). We first fitted a maximal model for each response variable that included all explanatory variables. We then tested the significance of each explanatory variable when removed from the maximal model. The variable with the lowest non-significant change in deviance was dropped and a reduced model was fitted with all remaining explanatory variables. This procedure was continued until either a subset or none of the explanatory variables was retained. Model comparison using ANOVA was employed to compare the maximal model with the final model to determine via $\chi^{2}$ tests the overall significance of the final models (Crawley 2007).

To manage any collinearity among the environmental attributes in the multivariate and univariate analyses, six variables (OM, N, Clay, Mg, P and $\mathrm{K}$ ) that were strongly correlated with each other and with $\mathrm{Ca}$ (correlations between $<-0.65$ and $>0.65$; Appendix 4) were excluded from the analysis; $\mathrm{Ca}$ was retained in the analysis to represent the suite of excluded correlated attributes (Quinn and Keough 2002). All univariate, multivariate and graphical analyses were performed using R 3.1.3 (R Core Team 2015), with packages stats (R Core Team 2015), vegan (Oksanen et al. 2015) and ggplot2 (Wickham 2009).

\section{Results}

We recorded a total of 131 plant species across all study sites (Appendix 2). Among the most widespread, each occurring across 10 or more of the 16 study sites, were four tree species (Eucalyptus piperita, E. sclerophylla, E. radiata, E. globoidea), four shrub species (Banksia spinulosa, Lomatia 
silaifolia, Hakea dactyloides, Hibbertia sericea), and six understorey species (Entolasia stricta, Lomandra longifolia, Goodenia bellidifolia, Pteridium esculentum, Poa sieberiana, Dampiera stricta).

We found that plant species composition varied significantly in relation to DGW $\left(\mathrm{F}_{1,13}=1.41, \mathrm{P}<0.05\right)$ and soil
$\mathrm{Ca}\left(\mathrm{F}_{1,13}=2.26, \mathrm{P}<0.001\right)$ across the sites, independently of the other measured environmental attributes (Fig. 3). Nine understorey species, representing only $7 \%$ of the pool of all plant species, were identified by SIMPER analysis as contributing to up to $50 \%$ of variation in species composition among the sites in relation to DGW. Patterns of abundance variation

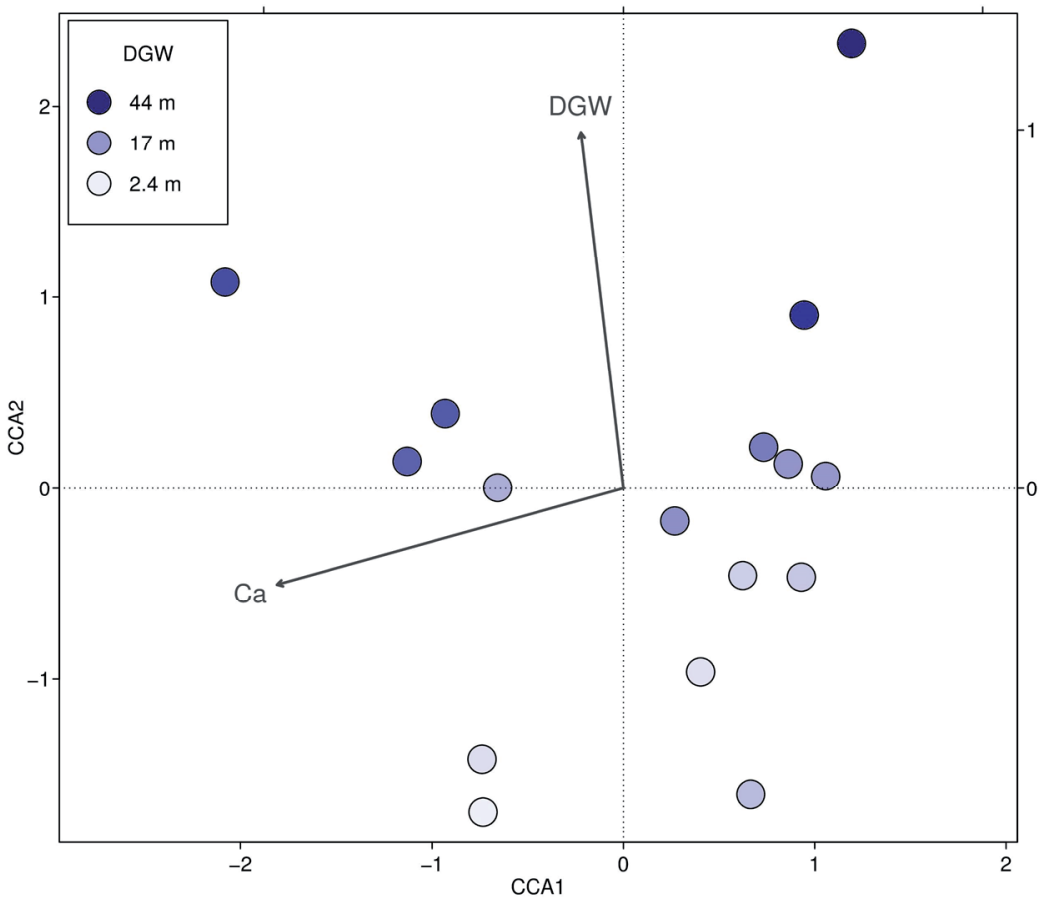

Figure 3. Ordination biplot from canonical correspondence analysis showing relationships between plant species composition and the significant environmental attributes depth-to-groundwater (DGW) and soil calcium content $(\mathrm{Ca})$. Circles are coloured by maximum DGW, shown in the box at top left.

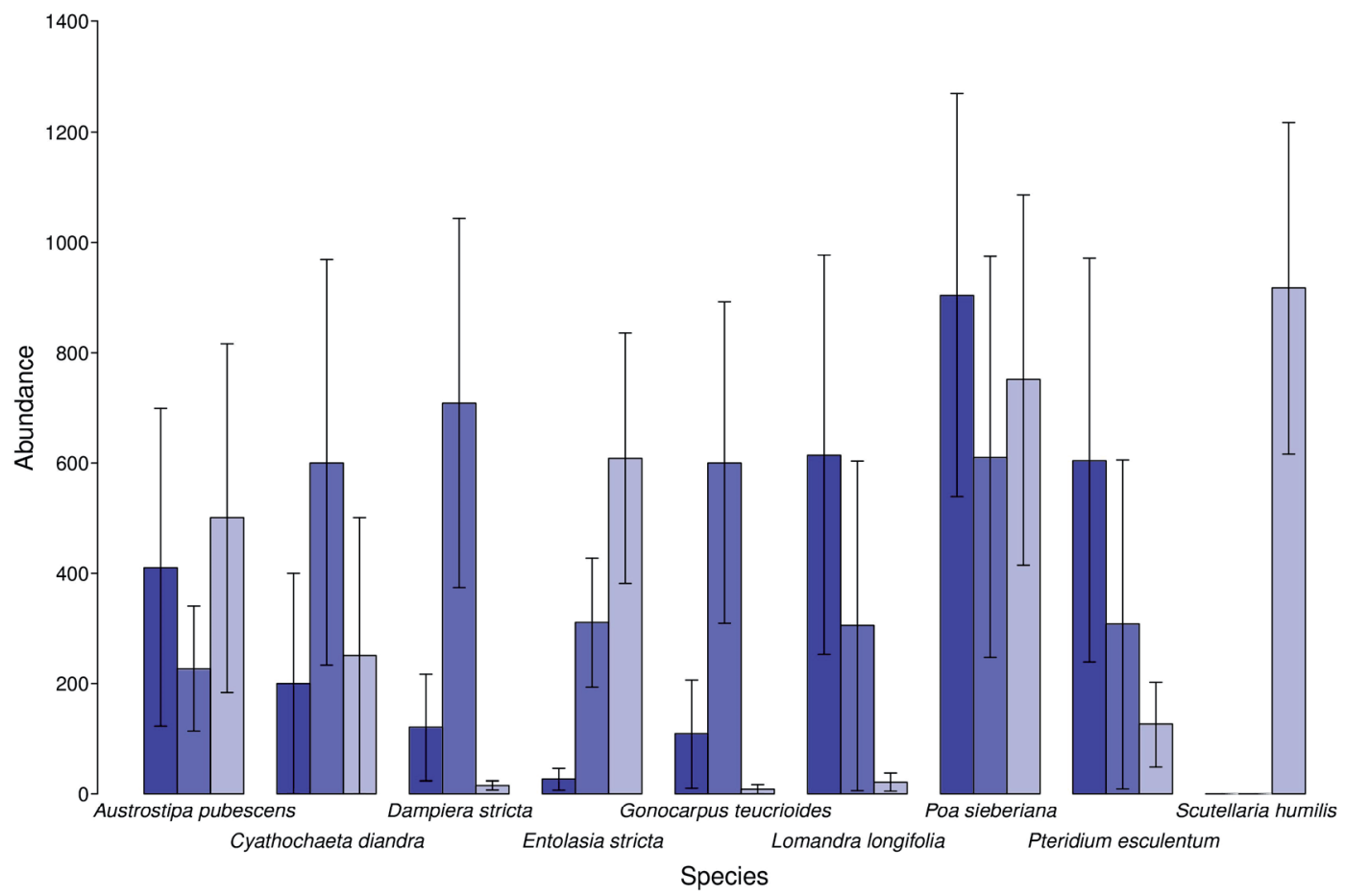

Figure 4. Mean abundances ( \pm SE) of the nine understorey species identified by SIMPER as contributing to $40-50 \%$ of variation in plant species composition along the depth-to-groundwater gradient. Depth-to-groundwater $<10 \mathrm{~m}$ (light shading), 12-22 $\mathrm{m}$ (moderate shading), and $27 \neg 44 \mathrm{~m}$ (dark shading). 


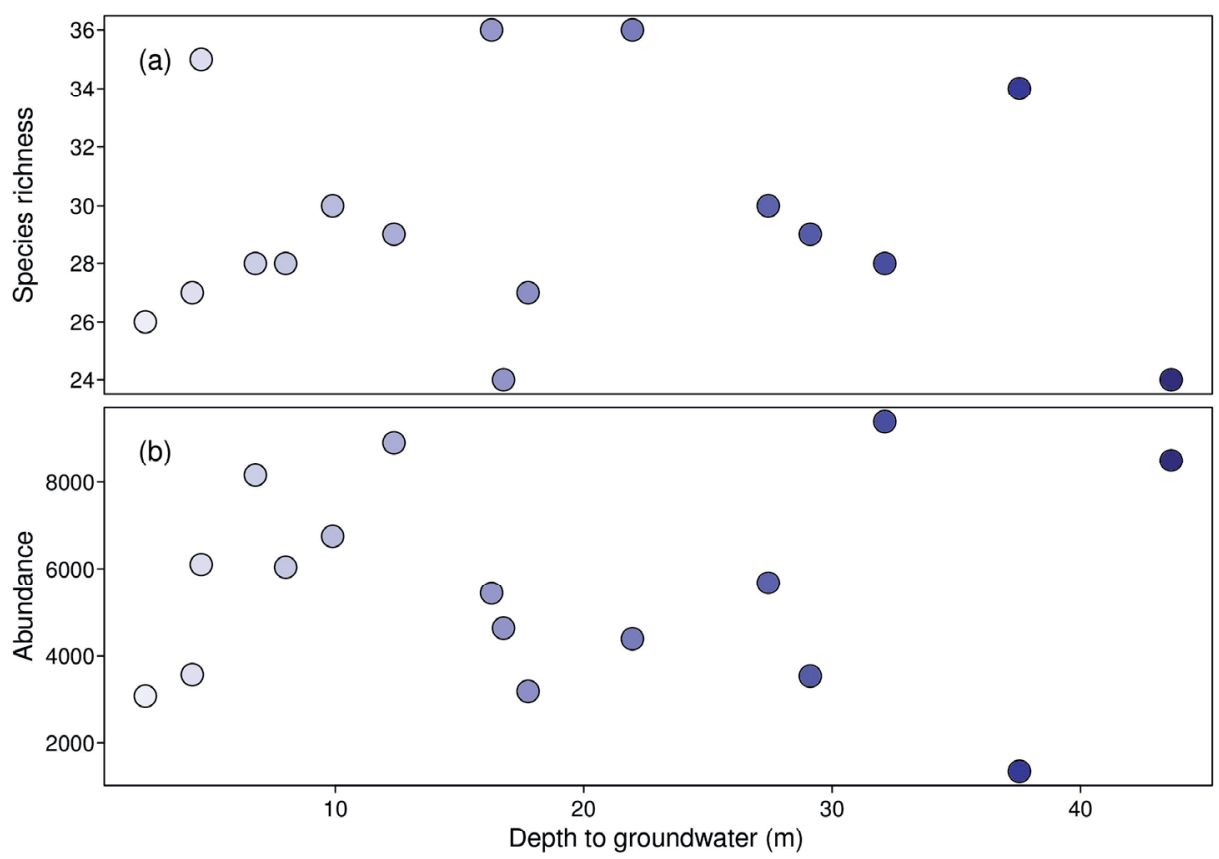

Figure 5.a. Plant species richness (number of species) and $\mathbf{b}$ : total plant abundance (number of individuals) as a function of DGW across the study sites. Depth-to-groundwater $<10 \mathrm{~m}$ (light shading), 12-22 m (moderate shading), and 27 $\neg 44 \mathrm{~m}$ (dark shading).

across the sites for each of these nine understorey species fell into one of four groups (Fig. 4), providing clear patterns of differentiation of species composition along the DGW gradient: (1) High abundances of the rush Lomandra longifolia and the bracken fern Pteridium esculentum at depths 27-44 m; (2) High abundances of the multi-stemmed herb Gonocarpus teucrioides and the groundcover perennial species Dampiera stricta and Cyathochaeta diandra at depths between 12 and $22 \mathrm{~m}$; (3) High abundances of the perennial herb Scutellaria humilis and the grass Entolasia stricta at depths $<10 \mathrm{~m}$; and (4) High abundances of the tussock grass Poa sieberiana and the spear grass Austrostipa pubescens at the deepest (27-44 $\mathrm{m})$ and shallowest $(<10 \mathrm{~m})$ sections of the gradient.

Across the sites, species richness ranged from 24-36 species and total plant abundance ranged from 1353-9398 individuals (Fig. 5). Our analyses revealed, however, that neither species richness nor total plant abundance varied significantly and independently as a function of DGW or any of the environmental attributes (richness: $\chi^{2}=3.75, \mathrm{DF}=8, \mathrm{P}=0.88$; abundance: $\chi^{2}=1.41, \mathrm{DF}=8, \mathrm{P}=0.99$ ).

\section{Discussion}

This study set out to determine whether plant species composition, richness and abundance varied in a systematic way in relation to a naturally occurring gradient in DGW in mesic woodlands. We found contrasting results for these different vegetation properties. Plant species composition varied significantly as a function of DGW, independently of the other attributes in the multivariate model. In addition, plant species composition was found to vary significantly and independently with soil $\mathrm{Ca}$ content, which represented several other soil attributes in the model. In contrast, however, despite showing site-to-site variation, neither plant species richness nor total plant abundance varied across the landscape in a systematic way in relation to either DGW or any of other measured environmental attributes.

We found that site-to-site variation in the abundance of nine understorey plant species was responsible for significant variation in plant species composition along the DGW gradient. This finding is consistent with the notion that compositional patterns in the understorey are a key driver of variation in plant species composition across landscapes (Specht and Specht 1993, Halpern and Spies 1995). In our study, abundance patterns of the nine understorey species are most likely explained by their differential abilities to tolerate either increasingly dry conditions at deeper DGW sites, and perhaps even the periodically waterlogged conditions at the shallower sites on the DGW gradient. During periods of extended drought at our study sites, for example the millennial drought of 2000-2008, the ecosystem became severely water limited. At sites with shallow groundwater, access to groundwater can mitigate the effects of drought for all species accessing groundwater. At sites with deep DGW, access to groundwater is absent for all species but drought has impacts on shallow rooted species first because the volume of soil explored by shallow rooted species is smaller than the volume explored by deeper roots species. Thus, understorey species at deep sites must be able to tolerate extended dry periods, in contrast to understorey species at shallow sites. Furthermore, soils dry out much faster at deep sites after rainfall than soils at shallow sites (Hingee, unpublished data), such that even during non-drought years, rainwater is available in the soil at deep sites for a shorter period of time for understorey species in 
particular. This could be because of periodic flooding occurring at the shallow sites after heavy rainfall which could lead to comparatively more saturated soils. There is also the possibility that soils at the shallow sites maintain higher moisture levels due to hydraulic lift from the capillary fringe located above the water table (Naumberg et al. 2005). At sites with intermediate DGW, shallow rooted species are also affected first as the deeper rooted species maintain connectivity to groundwater for longer.

High abundances of bracken fern (Pteridium esculentum) and the rush Lomandra longifolia at deep sites indicate that these understorey species are tolerant of dry conditions (Ahmad et al. 2009, ANBG 2012). It is not surprising that a species such as bracken fern is one of the dominant species at the deep sites, as it is an unusual fern that has a high degree of stomatal control of transpiration (Pitman 1989). This means that the stomata are able to tightly regulate transpiration rates when soil water content declines below a threshold (in contrast to anisohydric species that don't regulate transpiration down so readily), while its lignified stipe, rachis and stiff lamina help resist the effects of desiccation (Smith 1985). In addition, bracken fern is well suited to dry soil conditions as it has narrower and more rolled pinnulets with a more dissected frond structure (Thomson 2000). Bracken fern also exhibits extensively spreading mucilaginous rhizomes that serve as efficient water reservoirs (Smith 1985) and the species is capable of storing carbohydrate reserves (McGlone et al. 2005), facilitating growth and transpiration in conditions of low water availability. Carbohydrates are also strongly implicated in refilling of embolised xylem (Brodersen and McElrone 2013), a trait associated with adaptation to drier rather than wetter conditions. These traits allow bracken fern to tolerate dry soils and intermittent drought, which even enables the species to persist at the edge of the semi-arid zones in Australia (Cartledge and Carnahan 1971).

High abundances of the perennial herb Scutellaria humilis and the grass Entolasia stricta at shallow sites indicate that these species are most likely tolerant of periodic waterlogging. Although there are no quantitative data available about the frequency of waterlogging, our personal observations (M. Hingee, D. Eamus) are that waterlogging was apparent for several months in 2011 and 2012. Indeed, S. humilis is particularly abundant in moist habitats including along creek lines and in gullies. In New Zealand, species in the genus Scutellaria also commonly occur on the margins of watercourses where frequent flooding occurs (Williams 1992). The comparatively higher abundance of Dampiera stricta at sites with intermediate DGW suggests that this species is sensitive to both waterlogged soils and to the dry soils found at DGW deep sites. Gonocarpus teucrioides and Cyathochaeta diandra demonstrated a similar pattern of abundance variation along the gradient, and although their tolerance of waterlogged or very dry soils remains largely unexplored, the results of this study suggest that their ecophysiological traits might match those of $D$. stricta. Interestingly, the grass species Poa sieberiana was abundant across the gradient. The widespread nature of this species across the gradient suggests that the species is a generalist, able to attain moderate to high abundances across a range of different water availabilities.

We also found a significant relationship between plant species composition and soil $\mathrm{Ca}$, an element representing a suite of highly correlated environmental attributes in the analysis. While this study did not set out to test specific predictions about soil relationships with species composition, our findings are consistent with previous studies which have found that plant species composition varies in relation to a range of soil fertility measures, including soil N, P and $\mathrm{K}$ content (Critchley et al. 2002, Marini et al. 2007, Stevens et al. 2011). Indeed, this is why we included the wide range of environmental attributes in our analyses, as it is clearly important to consider other potential environmental correlates of plant species composition when examining the specific role of DGW. Future work that is focused specifically on the role of soil nutrients in shaping the composition of plant assemblages in Eucalyptus woodlands could start by developing explicit hypotheses about these soil nutrients.

Across the 2007 to 2012 period in the study region, temporal changes in DGW at all sites were generally less than 5\% and always less than $10 \%$. For example, data from Zolfagher (2013) show that at shallow (2.4 m), intermediate (13 m) and deep $(37.6 \mathrm{~m})$ sites, DGW varied by less than $0.5 \mathrm{~m}$ between 2007 and 2012. Importantly, this shows that temporal variation - both inter-annual and seasonal - in DGW at each site was much smaller than the differences in DGW between sites and that the ranking of DGW across the study sites used in this study did not vary. Thus, our finding for a significant and independent relationship between DGW and species composition across sites is principally due to the landscape gradient in DGW driving vegetation composition. Within each site in this particular study system, it is worth noting that vegetation does not appear to have major impacts that lead to substantial changes in depth to the water table. This is likely because annual rainfall in this mesic study area is relatively high. Between 2008 and 2012 annual rainfall exceeded 1100 $\mathrm{mm}$ except in 2009 (848 $\mathrm{mm}$ ). Recharge rates to aquifers are maintained in most years where water use by vegetation is typically $<50 \%$ of annual rainfall (Eamus et al. 2016). During the period 2011 to 2012 annual rates of vegetation water-use were estimated to be about $40 \%$ of rainfall (Zolfaghar 2013) and in our mesic study region with tall dense eucalypt forest (tree height 6-14 m; Zolfaghar et al. 2014) recharge was unlikely to have been compromised. This is a principle reason for this aquifer and region being selected as a future commercial bore-field for water extraction to drought-proof Sydney.

Should the Kangaloon study region be developed into a commercial bore-field, with the commencement of groundwater extraction to supplement metropolitan water supplies, declines in DGW may lead to considerable changes in the ecology of the woodlands. Indeed, Triassic fractured Hawkesbury Sandstone aquifers at Kangaloon, our study region, have been identified as prospective water supplies in emergency situations (Ross 2014). In situations where groundwater falls below natural ranges of depths tolerated by the woodlands, the first observable responses, especially where groundwater is close to the soil surface, are often a reduction in the abun- 
dance of shallow-rooted plant species (Elmore et al. 2006). For the woodlands in the Kangaloon region, this could potentially lead to the rapid local disappearance of shallow-rooted plant species already in low abundance at shallow sites. In addition, there may be reductions in abundance and potential extirpation of characteristic species at shallow sites such as Scutellaria humilis and Entolasia stricta. Such declines in abundance and local extinctions of native plant species are often followed by an increase in abundance of exotic plant species (Elmore et al. 2003). Although the native plant assemblages along the DGW gradient in the present study did not differ in species richness among shallow, intermediate and deep sites, exotic plant invasion and local reductions and extirpations of native plant species would undoubtedly combine to reduce native species richness most particularly at the shallow end of the gradient. If the species composition of plant assemblages is altered by exotic plant invasion in addition to groundwater extraction, costly procedures to restore and manage the woodlands may result (Scheffer et al. 2001, van de Koppel et al. 2002). In this context, the findings of our study can be used to guide monitoring efforts during any planned extraction of groundwater to ensure ecological integrity with regard to species composition in the woodlands. There is also the potential for our findings to be used to set ecological thresholds for sustainable groundwater extraction, thereby providing guidance for resource and conservation management.

Acknowledgements: We thank the Sydney Catchment Authority for providing access to depth-to-groundwater data from their groundwater monitoring bores, and J. Hopper for helpful comments on a draft of the manuscript.

\section{References}

Ahmad, N.M., P.M. Martin and J.M. Vella. 2009. Floral structure and development in the dioecious australian endemic Lomandra longifolia (Lomandraceae). Austr. J. Bot. 56: 666-683.

ANBG. 2012. Australian National Botanic Gardens. Vol. 2014, Australian Commonwealth, Canberra.

Benyon, R.G., S. Theiveyanathan and T.M. Doody. 2006. Impacts of tree plantations on groundwater in south-eastern Australia. Austr. J. Bot. 54: 181-192.

Bolker, B.M., M.E. Brooks, C.J. Clark, S.W. Geange, J.R. Poulsen, M.H.H. Stevens and J.S. White. 2009. Generalized linear mixed models: A practical guide for ecology and evolution. Trends Ecol. Evol. 24: 127-135.

Brodersen, C.R. and A.J. McElrone. 2013. Maintenance of xylem network transport capacity: a review of embolism repair in vascular plants. Frontiers Plant Sci. 4: 108.

Brown, J., L. Bach, A. Aldous, A. Wyers and J. DeGagné. 2011. Groundwater-dependent ecosystems in Oregon: an assessment of their distribution and associated threats. Frontiers Ecol. Environ. 9: 97-102.

Canadell, J., R. Jackson, J. Ehleringer, H. Mooney, O. Sala and E.D. Schulze. 1996. Maximum rooting depth of vegetation types at the global scale. Oecologia 108: 583-595.
Cartledge, O. and J. Carnahan. 1971. Studies of Austral bracken (Pteridium esculentum) in the vicinity of Canberra. New Phytol. 70: 619-626.

Chen, Y., H. Zilliacus, W.H. Li, H.F. Zhang and Y.P. Chen. 2006. Ground-water level affects plant species diversity along the lower reaches of the Tarim river, western China. J. Arid Environ. 66: 231-246.

Clarke, K.R. 1993. Non-parametric multivariate analyses of changes in community structure. Austr. J. Ecol. 18: 117-143.

Cook, P.G., T.J. Hatton, D. Pidsley, A.L. Herczeg, A. Held, A. O'Grady and D. Eamus. 1998. Water balance of a tropical woodland ecosystem, northern Australia: a combination of micro-meteorological, soil physical and groundwater chemical approaches. J. Hydrol. 210: 161-177.

Crawley, M.J. 2007. The R Book. John Wiley \& Sons Ltd, London.

Critchley, C., B. Chambers, J. Fowbert, R. Sanderson, A. Bhogal and S. Rose. 2002. Association between lowland grassland plant communities and soil properties. Biol. Conserv. 105: 199-215.

Eamus, D., T. Haton, P. Cook and C. Colvin. 2006a. Ecohydrology: Vegetation Function, Water and Resource Management. CSIRO Publishing, Melbourne.

Eamus, D., R. Froend, R. Loomes, G. Hose and B. Murray (2006b) A functional methodology for determining the groundwater regime needed to maintain the health of groundwater-dependent vegetation. Austr. J. Bot. 54: 97-114.

Eamus, D., S. Zolfaghar, R. Villalobos-Vega, J. Cleverly and A. Huete (2015) Groundwater-dependent ecosystems: recent insights from satellite and field-based studies. Hydrol. Earth Syst. Sci. 19: 4229-4256.

Eamus, D., A. Huete and Q. Yu (2016) Vegetation Dynamics: A Synthesis of Plant Ecophysiology, Remote Sensing and Modelling. Cambridge University Press, New York.

Elmore, A.J., S.J. Manning, J.F. Mustard, J.M. Craine. 2006. Decline in alkali meadow vegetation cover in California: the effects of groundwater extraction and drought. J. Appl. Ecol. 43: 770-779.

Elmore, A.J., J.F. Mustard and S.J. Manning. 2003. Regional patterns of plant community response to changes in water: Owens Valley, California. Ecol. Appl. 13: 443-460.

Groom, P.K., R.H. Froend and E.M. Mattiske. 2000. Impact of groundwater abstraction on a Banksia woodland, Swan Coastal Plain, Western Australia. Ecol. Manage. Restor. 1: 117-124.

Halpern, C.B. and T.A. Spies. 1995. Plant species diversity in natural and managed forests of the pacific northwest. Ecol. Appl. 5: 913-934.

Hatton, T. and R. Evans. 1998. Dependence of Ecosystems on Groundwater and its Significance to Australia. Land and Water Resources Research and Development Corporation, Canberra.

Hillel, D. 1971. Soil and Water: Physical Principles and Processes. Academic Press, New York

Jakeman, A.J., O. Barreteau, R.J. Hunt, J-D Rinaudo and A. Ross. 2016. Integrated Groundwater Management: Concepts, Approaches and Challenges. Springer International Publishing AG, Cham, Switzerland.

Jones, J.B. 2001. Laboratory Guide for Conducting Soil Tests and Plant Analysis. CRC Press, Boca Raton, Florida.

Kløve, B., P. Ala-Aho, G. Bertrand, J.J. Gurdak, H. Kupfersberger, J. Kværner, T. Muotka, H. Mykrä, E. Preda, P. Rossi, C.B. Uvo, E. Velasco and M. Pulido-Velazquez. 2014. Climate change impacts on groundwater and dependent ecosystems. J. Hydrol. 518 Part B: 250-266. 
Kodela, P. 1990. Pollen-tree relationships within forests of the Robertson-Moss Vale region, New South Wales, Australia. Rev. Palaeobot. Palynol. 64: 273-279.

Konikow, L.F. and E. Kendy. 2005. Groundwater depletion: a global problem. Hydrogeol. J. 13: 317-320.

Krishnamurty, K.V., E. Shpirt and M.M. Reddy. 1976. Trace meta extraction of soils and sediments by nitric acid -hydrogen peroxide. Atomic Absorption Newsletter 15: 67-80

Legendre, P. and E.D. Gallagher. 2001. Ecologically meaningful transformations for ordination of species data. Oecologia 129: 271-280.

Marini, L., M. Scotton, S. Klimek, J. Isselstein and A. Pecile. 2007. Effects of local factors on plant species richness and composition of alpine meadows. Agriculture, Ecosystems \& Environment 119: $281-288$

McCullagh, P. and J.A. Nelder. 1989. Generalized Linear Models. Second edition. Chapman and Hall, London.

McGlone, M.S., J.M. Wilmshurst and H.M Leach. 2005. An ecological and historical review of bracken (Pteridium esculentum) in New Zealand, and its cultural significance. New Zealand J. Ecol. 29: 165-184

Mendes, M.P, L. Ribeiro, T.S. David and A. Costa. 2016. How dependent are cork oak (Quercus suber L.) woodlands on groundwater? A case study in southwestern Portugal. Forest Ecol. Manage. 378: 122-130.

Murray, B.R., M.J.B. Zeppel, G.C. Hose and D. Eamus. 2003. Groundwater-dependent ecosystems in Australia: it's more than just water for rivers. Ecol. Manage. Restor. 4:110-113.

Murray, B.R., G.C. Hose, D. Eamus and D. Licari. 2006. Valuation of groundwater-dependent ecosystems: a functional methodology incorporating ecosystem services. Austr. J. Bot.54: 221-229.

Naumburg, E., R. Mata-gonzalez, R.G. Hunter, T. Mclendon and D.W. Martin. 2005. Phreatophytic vegetation and groundwater fluctuations: A review of current research and application of ecosystem response modeling with an emphasis on great basin vegetation. Environ. Manage. 35: 726-740.

Nevill, J.C., P.J. Hancock, B.R. Murray, W.F. Ponder, W.F. Humphreys, M.L. Phillips and P.K. Groom. 2010. Groundwaterdependent ecosystems and the dangers of groundwater overdraft: a review and an Australian perspective. Pacific Conserv. Biol. 16: $187-208$

NPWS. 2003. The Native Vegetation of the Woronora, O'Hares and Metropolitan Catchments. NSW National Parks and Wildlife Service, Hurstville.

O'Grady, A.P., J.L. Carter and K. Holland. 2010. Review of Australian Groundwater Discharge Studies of Terrestrial Systems. CSIRO: Water for a Healthy Country National Research Flagship. CSIRO, Melbourne.

Oksanen, J., G. Blanchet, R. Kindt, P. Legendre, P. Minchin, R.B. O’Hara, G. Simpson, P. Solymos, H. Stevens and H. Wagner. 2015. Vegan: Community Ecology Package. R package version 2.3-5. http://CRAN.R-project.org/package=vegan

Pérez-Harguindeguy, N., S. Díaz, E. Garnier, S. Lavorel, H. Poorter, P. Jaureguiberry, M.S. Bret-Harte, W.K. Cornwell, J.M. Craine, D.E. Gurvich, C. Urcelay, E.J. Veneklaas, P.B. Reich, L. Poorter, I.J. Wright, P. Ray, L. Enrico, J.G. Pausas, A.C. de Vos, N. Buchmann, G. Funes, F. Quétier, J.G. Hodgson, K. Thompson, H.D. Morgan, H. ter Steege, M.G.A van der Heijden, L. Sack, B. Blonder, P. Poschlod, M.V. Vaieretti, G. Conti, A.C. Staver, S. Aquino and J.H.C. Cornelissen. 2013. New handbook for standardised measurement of plant functional traits worldwide. Austr. J. Bot. 61: 167-234.
Pitman, J.I. 1989. Rainfall interception by bracken in open habitatsrelations between leaf area, canopy storage and drainage rate. $J$. Hydrol. 105: 317-334

Polglase, P. and R.G. Benyon. 2009. The Impacts of Plantations and Native Forests on Water Security: Review and Scientific Assessment of Regional Issues and Research Needs. Forest and Wood Products Australia, Melbourne.

Quinn, G.P. and M.J. Keough. 2002. Experimental Design and Data Analysis for Biologists. Cambridge University Press, Cambridge.

R Core Team. 2015. R: A language and environment for statistical computing. R Foundation for Statistical Computing, Vienna, Austria. URL http://ww.R-project.org/

Ross, J.B. 2014. Groundwater resource potential of the Triassic Sandstones of the Southern Sydney Basin: an improved understanding. Austral. J. Earth Sci. 61: 463-474.

Scheffer, M., S. Carpenter, J.A. Foley, C. Folke and B. Walker. 2001. Catastrophic shifts in ecosystems. Nature 413: 591-596.

Sivertsen, D. 2009. Native Vegetation Interim Type Standard. Department of Environment Climate Change and Water, Sydney.

Smith, R. 1985. Opportunistic behaviour of bracken (Pteridium aquilinum 1. Kuhn) in moorland habitats: origins and constraints. In: R. Smith and J. Taylor (eds.), Bracken: Ecology, Land Use and Control Technology. Parthenon Press, Leeds, pp. 215-224.

Sommer, B. and R.H. Froend. 2014. Phreatophytic vegetation responses to groundwater depth in a drying Mediterranean-type landscape. J. Veg. Sci. 25: 1045-1055.

Specht, A. and R.L. Specht. 1993. Species richness and canopy productivity of Australian plant communities. Biodivers. Conserv. 2: $152-167$.

Stevens, C., C. Dupre, C. Gaudnik, E. Dorland, N. Dise, D. Gowing, A. Bleeker, D. Alard, R. Bobbink and D. Fowler. 2011. Changes in species composition of European acid grasslands observed along a gradient of nitrogen deposition. J. Veg. Sci. 22: 207-215.

Stromberg, J.C., R. Tiller and B. Richter. 1996. Effects of groundwater decline on riparian vegetation of semiarid regions: the San Pedro, Arizona. Ecol. Appl. 6: 113-131.

ter Braak, C.J.F. 1987. The analysis of vegetation-environment relationships by canonical correspondence analysis. Plant Ecol. 69: 69-77.

Thomson, J.A. 2000. Morphological and genomic diversity in the genus Pteridium (Dennstaedtiaceae). Ann. Bot. 85: 77-99.

Thorne, R.S.J., W.P. Williams and Y. Cao. 1999. The influence of data transformations on biological monitoring studies using macroinvertebrates. Water Res. 33: 343-350.

van de Koppel, J., M. Rietkerk, F. van Langevelde, L. Kumar, C.A. Klausmeier, J.M. Fryxell, J.W. Hearne, J. van Andel, N. de Ridder and A. Skidmore. 2002. Spatial heterogeneity and irreversible vegetation change in semiarid grazing systems. Amer. Nat. 159: 209-218.

Wada, Y., L.P.H. van Beek, C.M. van Kempen, J.W.T.M. Reckman, S. Vasak and M.F.P. Bierkens. 2010. Global depletion of groundwater resources. Geophys. Res. Lett. 37: L20402.

Wickham, H. 2009. ggplot2: Elegant Graphics for Data Analysis. Springer Science \& Business Media, London.

Williams, P. 1992. Ecology of the endangered herb Scutellaria novaezelandiae. New Zealand J. Ecol. 16: 127-127.

Zhu, J., J. Yu, P. Wang, Q. Yu and D. Eamus. 2013. Distribution patterns of groundwater-dependent vegetation species diversity and their relationship to groundwater attributes in northwestern china. Ecohydrology 6:191-200. 
Zolfagher, S. (2013) Comparative Ecohysiology of Eucalyptus woodlands along a Depth-To-Groundwater Gradient. PhD thesis, University of Technology Sydney.

Zolfaghar, S., R. Villalobos-Vega, J. Cleverly, M. Zeppel, R. Rumman and D. Eamus. 2014. The influence of depth-to-groundwater on structure and productivity of Eucalyptus woodlands. Austr. J. Bot. 62: $428-437$

Zolfaghar, S., R. Villalobos-Vega, J. Cleverly and D. Eamus. 2015. Co-ordination among leaf water relations and xylem vulnerability to embolism of Eucalyptus trees growing along a depth-togroundwater gradient. Tree Physiol. 35: 732-743.

Received November 20, 2016 Revised January 31, 2017 Accepted March 1, 2017

\section{Electronic appendices}

Appendix 1. Geographic coordinates and depth-to-groundwater for the 16 study sites.

Appendix 2. Study species and their abundances (number of individuals, see Methods for details) at each of the 16 sites.

Appendix 3. Variation in environmental attributes across the 16 study sites.

Appendix 4. Pairwise correlation matrix between environmental attributes 